\title{
Equality, Vulnerability and Independence
}

Link to publication record in Manchester Research Explorer

\section{Citation for published version (APA):}

O'Neill, J., Bielskis, A. (Ed.), \& Knight, K. (Ed.) (2015). Equality, Vulnerability and Independence. In Virtue and Economy: Ashgate Publishing .

\section{Published in:}

Virtue and Economy:

\section{Citing this paper}

Please note that where the full-text provided on Manchester Research Explorer is the Author Accepted Manuscript or Proof version this may differ from the final Published version. If citing, it is advised that you check and use the publisher's definitive version.

\section{General rights}

Copyright and moral rights for the publications made accessible in the Research Explorer are retained by the authors and/or other copyright owners and it is a condition of accessing publications that users recognise and abide by the legal requirements associated with these rights.

\section{Takedown policy}

If you believe that this document breaches copyright please refer to the University of Manchester's Takedown Procedures [http://man.ac.uk/04Y6Bo] or contact uml.scholarlycommunications@manchester.ac.uk providing relevant details, so we can investigate your claim.

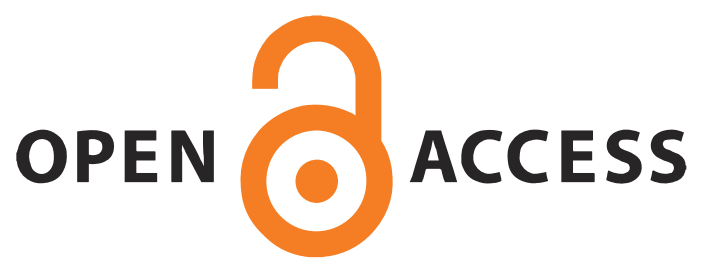




\section{Chapter 5}

\section{Equality, Vulnerability and Independence}

John O’Neill

In the opening chapter to Dependent Rational Animals Alasdair MacIntyre takes Adam Smith to exemplify a particular attitude of philosophers to the facts of human vulnerability, affliction and dependence. While Smith recognises the 'perspectives of ill health and old age' in which such facts are evident, he 'finds reason at once to put them aside' (MacIntyre 1999: 2). Thus on the one side, Smith recognises the existence of vulnerability and dependence:

While discussing what it is that makes the "pleasures of wealth and greatness ... strike the imagination as something grand and beautiful' he remarks that 'in the languor of disease and the weariness of old age' we ceased to be so impressed, for we then take note of the fact that the acquisition of wealth and greatness leaves the possessors 'always as much, and sometimes more exposed than before, to anxiety, to fear, and to sorrow; to diseases, to danger, and to death' (Smith, The Theory of Moral Sentiments, IV, chapter 1). (MacIntyre 1999: 2)

However, having acknowledged these facts of human dependence and vulnerability, Smith claims in better health we put such 'splenetic philosophy' aside and that it is good that we do so.

The imagination of those 'in better health or in better humor' fosters what may, Smith concedes, be no more that seductive illusions about the pleasures of wealth and greatness, but they are economically beneficial illusions. 'It is this deception which rouses and keeps in continual motion the industry of mankind'. (ibid.) 
In thus putting the facts of vulnerability and dependence aside Smith typifies the stance of philosophy: 'Smith speaks for moral philosophy in general' (ibid.). He is not the first to so speak. MacIntyre takes Aristotle to have anticipated him. However the two thinkers share the standpoint of the 'self-sufficiently superior' who are 'unable to give due recognition to affliction and to dependence' (ibid.: 7).

In this chapter I will consider these criticisms of Smith in detail with the aim of linking them with a wider tradition of egalitarian argument. I will do so by putting Smith's own work into dialogue with claims of contemporary authors which were more sensitive to the facts of human vulnerability and dependence, in particular those of Rousseau, and examining different lines of argument that emerge from these discussions. In section one I outline the central role of the value of independence plays in Smith's defence of commercial society. In section two I consider Smith's arguments in contrast to those of Rousseau to whom he was, among others, responding. In doing so I distinguish two different forms of criticism that might be made of Smith's arguments which have remained important to discussions of market economies. The first is that the independence in commercial society is partial and illusory. While commercial society is marked by new forms of personal independence, it also brings with it new forms of dependence. Versions of this claim are to be found in Marx in particular. The second is that which MacIntyre develops - that failure to acknowledge background states of dependency which are a condition of the virtues of independence leads to a mischaracterisation of those virtues. In developing that theme I want to relate it to a theme implicit in Rousseau - that mutual assistance which takes place under conditions of equality in which there exists mutual recognition of a symmetry in vulnerability allows the compatibility of dependence and self-respect which is absent where that symmetry and its recognition are absent. Equality is a condition for dependency to lose its potentially humiliating character. In the final section I outline the continuing legacy of that thread of egalitarian thought in particular in the work of Titmuss.

\section{Smith's Defence of Commercial Society}


Adam Smith's defence of commercial society turns on the claim that commercial society fosters the virtues of independence:

Nothing tends so much to corrupt and enervate and debase the mind as dependency, and nothing gives such noble and generous notions of probity as freedom and independency. Commerce is one great preventative of this custom. (Smith 1982c: vi.6)

Smith's defence of commercial society in these terms appeals to Stoic virtues: 'Every man, as the Stoics used to say, is first and principally recommended to his own care; and every man is certainly, in every respect, fitter and abler to take care of himself than of any other person' (Smith 1982b: VI.ii.1.1). Commercial society fosters the virtues of independence.

These claims remain at the core of Smith's arguments for commercial society in The Wealth of Nations:

[C]ommerce and manufactures gradually introduced order and good government, and with them, the liberty and security of individuals, among the inhabitants of the country, who had before lived almost in a continual state of war with their neighbours and of servile dependency upon their superiors. This, though it has been the least observed, is by far the most important of all their effects. (Smith 1981: III.IV.4)

Whereas in pre-commercial society the power of patronage and gift renders the poor dependent on the wealthy ${ }^{1}$, in commercial society ties of personal dependence are broken. Through the division of labour and relationships of exchange the economic interdependence of individuals is disassociated from personal dependence. The income of each worker is not tied to that of any

\footnotetext{
1 '[The great proprietor] is at all times ... surrounded with a multitude of retainers and dependants, who, having no equivalent to give in return for their maintenance, but being fed entirely by his bounty, must obey him ... Before the extension of commerce and manufacture in Europe, the hospitality of the rich, and the great, from the sovereign down to the smallest baron, exceeded everything which in the present times we can easily form a notion of' (Smith 1981: III.IV.5-6).
} 
particular individual. Hence, the powers that the rich previously exercised over their workers are broken. 'Though [the wealthy person] contributes, therefore, to the maintenance of them all, they are all more or less independent of him, because generally they can all be maintained without him' (Smith 1981: III.IV.11). This independence is not complete. Smith acknowledges a distinction between the fully independent artisan and the dependent servant and wage-worker (ibid.: I.viii.48). In entering the wage contract the worker lays down a portion, 'his liberty' in addition to his ease and happiness (ibid.: I.v.7). However, the wage worker is free of ties of personal dependence that marked the worker of pre-commercial society. While not absolutely independent, the wage worker is relatively independent.

These virtues of independence are also evident in the other often quoted sentence from The Wealth of Nations that MacIntyre cites in Dependent Rational Animals: 'It is not from the benevolence of the butcher, the brewer, or the baker that we expect our dinner, but from their regard to their own interest' (ibid.: I.II). There are two distinct points that Smith is making in the passage in which this sentence occurs which are evident in the two sentences that follow: 'We address ourselves, not to their humanity but to their self-love, and never talk to them of our own necessities but of their advantages. Nobody but a beggar chooses to depend chiefly upon the benevolence of his fellow-citizens'. The first of the sentences is about the possibility of a social order founded on self-love and limited benevolence. The second is about the possibility of a social order in which individuals relate to each other as independent agents.

The first claim is one that Smith defends in The Theory of Moral Sentiments and is standard in the commentaries on the passage in The Wealth of Nations: commercial society makes possible an order in which the strong bonds of benevolence are absent. Such bonds cannot be expected to extend beyond local communities of kin and friendship to the wider 'assembly of strangers' with whom individuals relate in commercial society (Smith 1982b: I.i.4.9). However, through market exchange, individuals can cooperate in the absence of such bonds: 
Society may subsist among different men, as among different merchants, from a sense of its utility, without any mutual love or affection; and though no man in it should owe any obligation, or be bound in gratitude to any other, it may still be upheld by a mercenary exchange of good offices according to an agreed valuation. (ibid.: II.ii 3.2)

While no society can exist in the absence of the rules and sentiments of justice governing negative responsibilities to avoid harm, the positive sentiments of beneficence are not required in a commercial social order. It is this claim that MacIntyre implicitly criticises in his discussion of the passage: 'market relationships can only be sustained by being embedded in certain types of nonmarket relationships, relationships of uncalculated giving and receiving' (MacIntyre 1999: 117).

However, Smith's arguments in the passages from The Wealth of Nations do not just turn on a negative claim about the limits of benevolence, but a positive claim about the virtues of those limits. In addressing others' self-love and not their benevolence, individuals realise the virtues of independence. A person obtains what he needs not though 'servile and fawning attention to obtain their good will' (Smith 1981: I.II.2), but rather though exchange between independent property holders. In contrast in pre-commercial societies governed by gift and patronage, the dependent do have to call upon the benevolence of the wealthy. It is in virtue of doing so that one is rendered dependent. Commercial society realises an order in which independent agents relate to others as independent agents. Individuals stand to each other neither as benefactor nor as dependent. The ethical appeal Smith is making here is to the Stoic virtues where persons are recommended to their own care and have standing as such, as a persons who are able to care for themselves.

This Stoic conception of independence to which Smith appeals elsewhere takes a still stronger form. Smith also denies the traditional doctrine defended by Aquinas and still evident in the work of Locke, that claims of necessity give an individual rights in the property of another (Aquinas: II.II 66.7; Locke 1988: I.42). Smith in contrast follows the Stoic doctrine found in 
Cicero, that for the virtuous agent poverty and even death are to be preferred to the injustice involved in taking what is the property of another: 'for one man to take from another and to increase his own advantage at the cost of another's disadvantage is more contrary to nature than death, than poverty, than pain and than anything else that may happen to his body or external circumstances' (Cicero 1991: III.21). In The Theory of Moral Sentiments Smith directly echoes this passage from Cicero in denying the poor rights in the wealth of the rich:

The poor man must neither defraud nor steal from the rich, though the acquisition might be much more beneficial to the one than the loss could be hurtful to the other ... There is no commonly honest man who does not more dread the inward disgrace of such an action, the indelible stain which it would forever stamp upon his own mind, than the greatest external calamity which, without any fault of his own, could possibly befal him; and who does not inwardly feel the truth of that great stoical maxim, that for one man to deprive another unjustly of any thing, or unjustly to promote his own advantage by the loss or disadvantage of another, is more contrary to nature, than death, than poverty, than pain, than all the misfortunes which can affect him, either in his body, or in his external circumstances. (Smith 1982a: III.3).. ${ }^{2}$

The virtuous agent is an independent agent for whom even poverty and death is better than transgressing the rules of property on which 'depend the whole security and peace of human society' (ibid.).

\section{Smith, Rousseau and the Virtues of Independency}

Smith, in claiming that commercial society realises the virtues of independence is responding to contemporary arguments that claimed to the contrary that it lead to dependence. A particular opponent is Rousseau who in A Discourse on the Origin of Inequality contrasts the 'free,

\footnotetext{
${ }^{2}$ For a discussion see Salter 1999. On the status of claims of necessity in The Wealth of Nations see Hont and Ignatieff 1983. For a contrasting view to the one presented here see Fleischacker 2004, chapter 10.
} 
healthful, humane and happy' lives of those in 'savage' society who 'continued to enjoy amongst themselves the sweets of an independent society' with the dependency of those in commercial society. The fall from original independence and freedom occurs when the individuals begin to see themselves through the eyes of others and where appearance gained through material possession is consequently divorced from character:

To be and to appear to be, became two things entirely different; and from this distinction arose imposing ostentation, deceitful guile, and all the vices which attend them. Thus man, from being free and independent, became by a multitude of new necessities subjected in a manner, to all nature, and above all to his fellow creatures, whose slave he is in one sense even while he becomes their master; rich, he has occasion for their services; poor, he stands in need of their assistance; and even mediocrity does not enable him to live without them. (Rousseau 1984, Smith translation, Smith 1982a: 119)

The translations from Rousseau here are those of Smith who picks out these passages as crucial to Rousseau's argument. Smith's defence of commercial society as a sphere in which independence is realised is aimed in part against Rousseau's rejection of commercial society. Smith accepts that accumulation of wealth in commercial society is driven vanity, for a desire for appearance:

For to what purpose is all the toil and bustle of this world? What is the end of avarice and ambition, of the pursuit of wealth and power, and preeminence? Is it to supply the necessities of nature? The wages of the meanest labourer can supply them ... From whence, then, arises that emulation which runs through all the different ranks of men, and what are the advantages which we propose by that great purpose of human life which we call bettering our condition? To be observed, to be attended to, to be taken notice of with sympathy, complacency and approbation, are all the advantages which we can propose to derive from it. It is vanity, not the ease, or the pleasure, which interests us. But vanity is always founded upon the belief of our being the object of attention and approbation. The rich man glories in his riches, because he feels that they draw upon him the attention of the world ... (Smith 1982b: 50) 
However, while this vanity is allowed to be 'the great and most universal cause of corruption of our moral sentiments' (ibid.: I.iii.3.1), Smith inverts Rousseau's view of its consequences. Consider another passage Smith translates from the Discourses on Inequality:

But from the instant in which one man had occasion for the assistance of another, from the moment that he perceived that it could be advantageous to a single person to have provisions for two, equality disappeared, property was introduced, labour became necessary, and the vast forrests of nature were changed into agreeable plains, which must be watered with the sweat of mankind, and in which the world beheld slavery and wretchedness begin to grow up and blosom with the harvest. (Rousseau 1984, translated by Smith 1982a: 252).

As the editors of the Glasgow edition of The Theory of Moral Sentiments note, the final sentences of this passage reappear in a very different context in that book:

The pleasures of wealth and greatness, when considered in this complex view, strike the imagination as something grand and beautiful and noble, of which the attainment is well worth all the toil and anxiety which we are so apt to bestow upon it ... It is this deception which rouses and keeps in continual motion the industry of mankind. It is this which first prompted them to cultivate the ground, to build houses, to found cities and commonwealths, and to invent and improve all the sciences and arts, which ennoble and embellish human life; which have entirely changed the whole face of the globe, have turned the rude forests of nature into agreeable and fertile plains, and made the trackless and barren ocean a new fund of subsistence, and the great high road of communication to the different nations of the earth. (Smith 1982b: IV.1.9-10)

Smith's account inverts the critical force of Rousseau's arguments about commercial society and dependence. It appears as part of a defence of commercial society. The paragraph in which this passage appears ends in the invisible hand metaphor, here in The Theory of Moral Sentiments as a link between the 'natural selfishness and rapacity' of the rich and a 'distribution of the necessaries of life, which would have been made, had the earth been divided into equal 
portions among all its inhabitants' (ibid.: IV.1.10). However, it is not merely the distribution of necessities that matters here, but the conditions for independence. As we have seen for Smith, in commercial society, through the division of labour and exchange, each person is freed from personal dependence and realises the Stoic virtues of independence. Rousseau's position is inverted.

This argument about the relation of commercial society and independence is the start of a history of a debate about the relation of commercial society and independence. There are two distinct varieties of criticism both of which are variations on themes that can be found in Rousseau. The first is that the apparent independence fostered by commercial society disguises new forms of dependence. A version of the claim appears in the work of Kant:

$[\mathrm{M}]$ oney makes one independent, one gains respect by the possession of it; one has worth, needs no one and depends on no one. But in making us independent of others, money in the long run makes us dependent on itself; it frees us from others in order to enslave us. (Kant 1979: 177)

More significantly the claim that the independence realised in commercial society is partial and illusory is a central theme in Marx. In the early writing the divorce of real character and appearance and the forms of dependency it is taken to produce are to be found in the Economic and Philosophical Manuscripts:

Under private property ... every person speculates on creating a new need in another, so as to drive him to fresh sacrifice, to place him in a new dependence ... Each tries to establish over the other an alien power ... (Marx 1974: 358)

In the later works the theme remains although with a stronger emphasis on the achievements of commercial society in realising personal independence. Marx accepts that a virtue of a commercial society based on exchanges relations is that it destroys the forms of personal dependence that existed in pre-commercial society: 'In the money relation, in the developed system of exchange ... the ties of personal dependence ... are in fact exploded, ripped up ... ; and individuals seem independent ...' (Marx 1973: 163). However, the independence is 
only apparent not real. It is 'an independence which is at bottom merely an illusion' (ibid.). The independence is taken to be illusory for two reasons. The first concerns the form that the independence takes. While personal dependence may be absent, it is not replaced by independence as a social virtue. Independence realised through monetary exchange is 'more properly called indifference' (ibid.). Second, while personal dependence might be an achievement of commercial society, it is replaced by what Marx calls 'objective dependency'. The objective dependence takes at least two forms. First, there is the specific form it takes for the worker. While the worker in owning his own labour power is not personally dependent on any particular owner of capital, he must sell his labour power to some capitalist. Second, there is the general form in which it affects all members of modern commercial societies. All are the 'plaything of alien powers', dependent on the impersonal workings of market society. Full independence requires that objective dependence of this form is overcome through social relations being brought under the 'communal control' of individuals (ibid.: 162).

The argument about the degree to which commercial society does actually realise independence forms then one major theme in the discussion commercial society. However, it needs to be kept distinct from a second line of criticism that MacIntyre invokes. This line of argument plays not on the illusory nature of independence in commercial society, but the particular characterisation of the virtues independence offered by Smith and, in particular, its failure to properly recognise and acknowledge the background states of dependency which are a condition of the virtues of independence. Smith represents the standpoint of 'self-sufficiently superior' who is 'unable to give due recognition to affliction and to dependence' (MacIntyre 1999: 7). The virtues of independence are mischaracterised by Smith in virtue of this failure.

One way of reformulating this point is in terms of an Aristotelian characterisation of the virtues of independence. John Benson has noted that the virtues of autonomous or independent character are typically characterised only in terms of contrast with the vices of deficiency. Autonomy is contrasted with heteronomy. Independence is contrasted with dependence. While these 
vices are undoubtedly vices, this characterisation is partial since it fails to recognise the vices of excess. The virtues of the autonomous or independent character need to be contrasted not only with vices of deficiency, but also those of excess:

The virtue of autonomy is a mean state of character with regard to reliance on one's own powers in acting, choosing and forming opinions. The deficiency is termed heteronomy, and there are many terms which may be used to describe the heteronomous person, some of which suggest specific forms of the vice: credulous, gullible, compliant, passive, submissive, overdependent, servile. For the vice of excess there is no name in common use, but solipsism might do, or arrogant self-sufficiency. (Benson 1983: 5)

Benson's claim that no term exists for the vices of excess is a telling one. Not only is the existence of these vices often unrecognised, as I have argued elsewhere often celebrated as virtues (O’Neill 1998: chs. 5-7). Forms of human dependence and the limits of self-sufficiency go unacknowledged.

While these points are well-made, there is a question as to how far they give a fair characterisation of Adam Smith. As MacIntyre notes, Smith does recognise the fact of human dependence (MacIntyre 1999: 2). Smith is sensitive to the limits of human self-sufficiency and the inescapable fact of human dependence: 'All the members of human society stand in need of each others assistance, and are likewise exposed to mutual injuries' (Smith 1982b: 85). This mutual dependence is grounded in our biological frailties that wealth and social power cannot in the end overcome. Human beings begin their existence in complete dependence on others: 'In the natural state of things ... the existence of the child, for some time after it comes into the world, depends altogether upon the care of the parent' (ibid.: VI.ii.1.3). Furthermore in passages that MacIntyre cites, Smith recognises that in illness and old age these facts of human dependence force themselves on us.

In the languor of disease and the weariness of old age, the pleasures of the vain and empty distinctions of greatness disappear ... Power and riches appear then 
to be, what they are, enormous and operose machines contrived to produce a few trifling conveniences to the body, consisting of springs the most nice and delicate, which must be kept in order with the most anxious attention .... They keep off the summer shower, not the winter storm, but leave him always as much, and sometimes more exposed than before, to anxiety, to fear, and to sorrow; to diseases, to danger, and to death. (ibid.: IV.1.8)

It would be false then to say that Smith does not recognise the inescapable facts of human dependence. Smith's point is rather that these facts are rarely recognised and it is good that this is the case. Economic life thrives when we forget these facts and power and riches appear as objects of desire.

But though this splenetic philosophy, which in time of sickness or low spirits is familiar to every man, thus entirely depreciates those great objects of human desire, when in better health and better humour, we never fail to regard them under a more agreeable aspect. (ibid.: IV.1.9).

The flourishing of commercial society depends upon on the self-deception of those involved about these biological limits of self-sufficiency, in which the truths of 'splenetic philosophy' go unrecognised.

It is this deception which rouses and keeps in continual motion the industry of mankind. (ibid.: IV.1.10)

These passages on unacknowledged dependence are followed by the appearance of the invisible hand in The Theory of Moral Sentiments quoted above. The self-deception has beneficial outcomes - the improvement of the condition of the poor.

Smith's arguments again contrast with those of Rousseau whose version of egalitarianism moved in the opposite direction of a fully splenetic philosophy. The truths of splenetic philosophy - the acknowledgement of mutual vulnerability and dependence - form the basis of a social order in which mutual assistance is premised on the fact that 'tomorrow, any one may himself be in the same position as the one he assists is in today' (Rousseau 1911: Book IV, 185). This roughly 
egalitarian order contrasts with the one-sided relations in which one party takes itself to lack those vulnerabilities.

Why have kings no pity on their people? Because they never expect to be ordinary men. Why are the rich so hard on the poor? Because they have no fear of becoming poor. Why do the nobles look down upon the people? Because a nobleman will never be a commoner ... So do not train your pupil to look down from the height of his glory upon the sufferings of the unfortunate, the labours of the wretched, and do not hope to teach him to pity them as long as he considers them as far removed from himself. Make him clearly thoroughly aware of the fact that the fate of these unhappy persons may one day be his own, that his feet are standing on the edge of an abyss, into which he may be plunged at any moment by a thousand unexpected irresistible misfortunes ... (ibid.).

Rousseau's defence of the claim - the consciousness of vulnerability is a condition for the exercise of pity - appeals to a particular account of the emotion of pity. Those who take themselves to be invulnerable are unable to feel pity since the belief that a like misfortune could befall oneself is constitutive of the emotion of pity: 'we never pity another's woes unless we may suffer in like manner ourselves' (ibid.). In claiming that pity is constituted by the possibility that like misfortune could befall one, Rousseau is following a line of argument found in Aristotle and Hobbes. ${ }^{3}$ Thus Aristotle characterises pity thus:

Pity may be defined as a feeling of pain caused by the sight of some evil, destructive or painful, which befalls one who does not deserve it, and which we might expect to befall ourselves or some friend of ours, and moreover to befall us soon. (Aristotle 1946: 85b12ff)

Hobbes offers a characterisation couched in similar terms:

Griefe, for the Calamity of another, is pitty; and ariseth from the imagination that the like calamity may befall himselfe; and therefore is called also

\footnotetext{
${ }^{3}$ See also the discussion in Nussbaum 2001: $315 \mathrm{ff}$.
} 
COMPASSION, and in the phrase of this present time a fellow-feeling ... .

(Hobbes 1968: 126)

Smith in Book VII of The Theory of Moral Sentiments explicitly rejects this Hobbesian account of the pity or compassion. In distancing his own account from the Hobbesian view that appears to ground the feelings of pity and compassion in self-love or 'selfish principles' he suggests that we can feel pity or compassion for persons whose situation is such that we know we could not suffer. The possibility of compassion is founded not simply on imagining ourselves to have fallen into the situation of another, but imagining them in their own person: 'I consider what I should suffer if I was really you, and I not only change circumstances with you, but I change persons and character' (Smith 1982b: VII.iii.I.4). A man can feel sympathy with another for the loss of his son or for a woman in childbirth while knowing that these are situations he cannot face: 'A man may sympathize with a woman in child-bed; though it is impossible that he should conceive of himself as suffering her pains in his own proper person and character' (ibid.). ${ }^{4}$ There are large questions to be raised as to whether this account of sympathy in the later Book VII is consistent with the account that Smith introduces earlier in The Theory of Moral Sentiments in which sympathy, and more specifically compassion, is understood in terms of our imagining ourselves in our own person being in the same situation as the other: 'The compassion of the spectator must arise altogether from the consideration of what he himself would feel if he was reduced to the same unhappy situation, and, what perhaps is impossible, was at the same to time able to regard it with his present reason and judgment' (ibid.: I.i.1.11). It is this account of placing oneself in the situation of the other which informs his account of moral judgement in terms of the

\footnotetext{
${ }^{4}$ Smith as is often observed uses the term 'sympathy' in a much more general sense than with reference to pity or compassion: 'Pity and compassion are words appropriated to signify our fellow felling with the sorrow of others. Sympathy, though its meaning was, perhaps originally the same, may now, however, without much impropriety, be made use of to denote our fellow-feeling with any passion whatever' (Smith 1982b: I.i.I.5). However, in this context Smith's examples are specifically with compassion and pity as forms of sympathy.
} 
correspondence or non-correspondence of sympathetic emotions of the spectator and the agent in a particular situation (ibid. I.i.3.1). However, whatever story can be told about the internal consistency of Smith's position, there is something right about the claim that we can feel compassion for those in a situation we know that will not and cannot befall us. While there may be epistemic limits on fellow-feeling - imagination is not a substitute for the direct experience of a particular condition - the possibility of pity as such is not ruled out. To the extent to which Rousseau's argument depends on claims about the impossibility of pity in the absence of the possibility of a situation befalling us, the arguments fail.

There is, however, another aspect of Rousseau's argument in Emile that is more telling. Rousseau draws a distinction between conditions in which mutual assistance takes place under mutual recognition of a symmetry in vulnerability - in which 'tomorrow, any one may himself be in the same position as the one he assists is in today' (Rousseau 1911: 185) - and conditions where there is an asymmetry of vulnerabilities - in which 'look down from the height of his glory upon the sufferings of the unfortunate' (ibid.). A point that is implicit in that contrast is the very different social meanings that attached to acts of beneficence in those different contexts. In conditions of where vulnerabilities are symmetrical expressions of pity can be understood as expressions of solidarity or fellow feeling. In conditions of inequality they cannot be thus understood. They rather can take on properties of condescension and charity. Where the benefactor appears to 'look down from the height of his glory upon the sufferings of the unfortunate', the beneficiary is transformed into an object of dependency. ${ }^{5}$

\footnotetext{
${ }^{5}$ The distinction is now commonly marked between compassion and pity, where pity is taken to involve condescension that need not be involved in the attitude of compassion. This distinction is a relatively recent one that is absent in the use of the terms pity and compassion by Hobbes, Rousseau and Smith. For discussions see Blum 1994: 177-8, Nussbaum 2001: 301-2, Crisp 2008: 233.
} 
Smith's own observations about the view of poverty from those with wealth in places sound harsh. He claims, addressing clearly a particular readership, that while we may feel for sympathy for a person who falls from wealth into poverty, those who are simply in poverty are objects of contempt: 'The mere want of fortune, mere poverty, excites little compassion. Its complaints are too apt to be the objects rather of contempt than fellow feeling' (Smith 1982b: III.3.18). However, it is clear elsewhere that this contempt is not an attitude that Smith is necessarily endorsing. It is a source of the corruption of the moral sentiments:

The disposition to admire, and almost to worship, the rich and powerful, and to despise, or at least, to neglect persons of poor and mean condition, though necessary to establish and to maintain the distinction of ranks and order of society, is, at the same time, the great and most universal cause of corruption of our moral sentiments. That wealth and greatness are often regarded with the respect and admiration which are due only to wisdom and virtue; and that the contempt, of which vice and folly are the only proper objects, is often most unjustly bestowed upon poverty and weakness ... (ibid.: I.iii.3.1).

However, while the conflict between the corruption of the sentiments on the one hand and the maintenance of ranks and order on the other runs through The Theory of Moral Sentiments, in the end in the work of Smith it is decided in favour of the latter.

Nature has wisely judged that the distinction of ranks, the peace and order of society, would rest more securely upon the plain and palpable difference of birth and fortune, than upon the invisible and often uncertain difference of wisdom and virtue. The undistinguishing eyes of the great mob of mankind can well enough perceive the former: it is with difficulty that the nice discernment of the wise and the virtuous can sometimes distinguish the latter. (Smith 1982b: VI.ii.1.21) 
The attitudes to wealth and poverty are treated naturalistically as the necessary consequences of human psychology. ${ }^{6}$ The attitudes are ultimately defended by Smith as a condition for social order: 'The peace and order of society, is of more importance than even the relief of the miserable' (ibid.). Smith's discussion of virtues of independence takes place against the background of an assumed inequality of ranks. What is absent from Smith's discussion is an account of networks of assistance that might take place in modern conditions in the absence of the distinction of ranks.

To make this point is not to make some ahistorical judgement on Smith from a later egalitarian perspective. The assumption that a rough equality in vulnerabilities creates condition of mutual assistance without dependence found practical expression in the institutions of mutual aid that developed in eighteenth century working class communities. Consider for example the Rules and Orders of the Honourable Society of Workington written in February 2nd, 1792 just two years after the sixth edition of The Theory of Moral Sentiments':

When we look upon mankind as being subject to an innumerable train of evils and calamities, resulting either from pain or sickness, or the infirmities of old age, which render them unable to procure even a scanty subsistence, when at the same time they are made capable of the noblest friendship, common prudence induces us so to form ourselves into society, that the insupportable condition of the individual may, by the mutual assistance and support of the whole, become tolerable ... (c.f. Gray 2001)

In conditions where vulnerabilities are roughly equal, acknowledged dependence on others and the receipt of assistance are not associated with the asymmetries of power or the loss of standing

\footnotetext{
${ }^{6}$ These attitudes for Smith have their origin in human cognitive limits to properly discern virtue on the one hand and in our psychological dispositions with respect to joy and sorrow on the other. It is in virtue of 'our propensity to sympathize with joy is much stronger than our propensity to sympathize with sorrow' (Smith 1982b: I.iii.1.5) that our admiration for wealth ultimately arises: 'It is because mankind are disposed to sympathize more entirely with our joy than with our sorrow, that we make parade of our riches, and conceal our poverty' (1982b: I.iii.2.1).
} 
as an independent agent which Smith properly criticises as features of patronage in precommercial society. In conditions of equality, the existence and recognition of common vulnerability to evil and calamity robs the fact of dependency of any potentially humiliating condition.

\section{Dependency and Equality}

The thought that equality is a condition for dependency to lose its potentially humiliating character is one that has marked an important strand of egalitarian thought that appeals back to these traditions of experience of mutual aid in conditions of common vulnerabilities that marked the early history of working class movements (Tawney 1964: 40ff; Titmuss 1987: 122; Mauss 2002: 89). One expression of this egalitarian strand that deserves to be more widely discussed is to be found in the work of Richard Titmuss. Modern forms of dependency and the problems they create lie at the heart of Titmuss's account of social welfare:

[S]tates of dependency' arise for the vast majority of the population whenever they are not in a position to 'earn life' for themselves and their families; they are dependent people. In industrial societies there are many causes of dependency; they may be 'natural dependencies' as in childhood, extreme old age, and childbearing. They maybe causes by physical and psychological ill-health and incapacity, in part these are culturally determined. Or they may be wholly or predominantly determined by social and cultural factors. These may be said to be the 'man-made' dependencies. (Titmuss 1987: 46)

The central question becomes how one can render compatible the reality of these forms of natural and 'man-made' dependence with social independence. Titmuss rejects market solutions to the problem of dependence for at least two reasons. First, market relations do not require care for others, including strangers: 'one of the functions of atomistic private market systems is to free men from any sense of obligation to or for other men' (Titmuss 1970: 239). Second, markets are not an appropriate response to many natural and cultural dependencies. Dependencies that result from age, ill-health and natural incapacities render individuals unable to act as independent agents in 
markets and hence leave them unprotected by market mechanisms. Failures of the market itself are the source of many of the modern 'man-made' dependencies such as unemployment and underemployment.

Titmuss's well known work on the gift relationship is invoked in response to the market model of interdependence. The appeal is to a very particular gift relationship which is marked by a rough equality between participants in their capacities and vulnerabilities. The gift relationship as such need involve no egalitarian relationships. There is nothing essentially egalitarian about gift relationships. When one turns to the anthropological literature to which Titmuss himself appeals, it is clear that the opposite can be true. Gift and counter-gift in many traditional gift economies is part of a display of power and status. A gift places the receiver within a relationship of dependency and debt, a counter-gift restores equality. As such gift-giving and receiving can take competitive forms of assertion and counter-assertion of power and status, most famously in forms of potlatch. Thus as Mauss puts it:

Between chiefs and vassals, between vassals and their tenants, through such gifts a hierarchy is established. To give is to show one's superiority, to be more, to be higher in rank, magister. To accept without giving in return, or without giving more back, is to become client and servant, to become small, to fall lower (minister). (Mauss 1990: 74)

A similar point is, as we noted earlier, central to Smith's defence of commercial society. Conspicuous gift giving is part of the ties of dependence that commercial relations undermine. The gift serves as a means by which the wealthy exercise power and the poor are rendered dependent. The virtue of commerce on this account is that through exchange and the division of labour the relations of the worker to the wealthy no longer exhibit ties of personal dependence.

The concept of a gift relationship cannot then be invoked in any simple sense to exhibit institutional relations of the kind found in an egalitarian community. Nor does Titmuss claim it does. Titmuss recognises there are particular features of the gift relationship involved in blood donation which mark it off from other gift relations. It is impersonal; it takes place in the context 
of a rough equality of vulnerabilities and capacities; the exercise of the capacity of the gift is socially unmarked (Titmuss 1970: 74). Consider first the impersonality of the gift. While the gift takes place in a context of natural dependence of a strong kind - there is a strong asymmetry of needs in the context - it takes place in a context of social independence. It is normally a relation between strangers who are unknown to each other. It is in that sense an impersonal relationship, with no ongoing ties between the agents. Second, the donation also takes place in the context of a rough equality of vulnerabilities. While there may be particular groups like haemophiliacs who are in particular need of the gift and not able to reciprocate, blood is something that anyone could at some stage in their lives require. Anyone could become a recipient for all that they hope that will not need to be. Third, the capacity to give is likewise socially unmarked - it is a capacity possessed by any healthy adult irrespective of wealth or status. It is an anonymous gift that bestows no special status on the donor, a point that is explored beautifully in Galton and Simpson's The Blood Donor which exploits the inappropriateness of Tony Hancock's snobbery.

Tony Well - it's a grand job we're all doing. (Pause) Yes, I think we can all be very proud of ourselves. (Pause) Some people, all they do is take, take, take out of life, and never put anything back. Well that's not my way of living, and never has been. Never has been. You're only entitled to take out of life what you are prepared to put into it. (To man) Do we get a badge for doing this?

Man No, I don't think so.

Tony Pity. We should have something people to pick us out by.

Man Not really important, is it? As long as we give the blood and help someone, that's the main thing.

Tony Oh well, quite, quite, I mean as long as they get their corpuscles, quite, quite. That's reward in itself, I agree, no names, no pack drill, quite, quite. I just think we ought to get a badge as well. I mean nothing grand, a little enamelled thing, a little motto that's all, nothing pretentious, something like 'He gaveth for others so that others may live. (Galton and Simpson 1974: 104-5) 
It is in part because of these features of blood donation that this gift relationship has its power against a contractual model of human relations which we have seen is often invoked in contrast to the social dependence of pre-modern societies, including those dependencies that themselves are based on gift. Like the contract it is an impersonal relation between equals. Unlike the contract blood donation expresses not an instrumental relationship between self-subsistent agents but an expression of care which recognises mutual natural dependencies to which we are all vulnerable. It is as such that it expresses the kinds of social relations between equals that are central to the case for a communitarian egalitarianism. Hence the central contrast in The Gift Relationship between market and non-market spheres of interdependence.

In not asking for or expecting any payment of money these donors signified their belief in the willingness of other men to act altruistically in the future, and to combine together to make a gift freely available should they have a need for it ... As individuals they were, it may be said, taking part in the creation of a greater good transcending the good of self-love. To 'love' themselves they recognised the need to 'love' strangers. By contrast, one of the functions of atomistic private market systems is to free men from any sense of obligation to or for other men. (Titmuss 1970: 239)

For this reason, the introduction of a market system in blood undermines a social sphere of mutual care between equals.

While Titmuss is best known for his work on the gift relationship the general theme in his thought about the need to respond to dependence without humiliating the recipients is also to be found elsewhere in his work. For example it informs his discussion of means-tested benefits. One argument for the policy of means-testing benefits is that it offers a more just distribution of goods by targeting those in most need. The thought runs something as follows: "'let us concentrate help on those whose needs are greatest"; "why provide benefits for those who do not really need them"” (Titmuss 1987: 130). Titmuss's objection to this approach focuses on the loss of dignity and selfrespect associated with the means test. Selective means tested services fail 'to understand the 
indignities of expecting the poor to identify themselves as poor people and to declare, in effect, "I am an unequal person"" (Titmuss 1987: 203). Hence the problem that Titmuss outlines for providers of social services: 'How to include poor people ... and at the same time channel proportionately more resources in their favour without inducing shame and stigma' (Titmuss 1987: 129). ${ }^{7}$

Titmuss's egalitarianism is one that starts from the facts of vulnerability and dependence. It also belongs to that thread of egalitarianism according to which equality matters in virtue of the social relationships of which it is constitutive. It is not possible to sustain 'true community where great disparities of income and wealth preside' (Titmuss 1987: 121). This egalitarianism informs what Titmuss characterises as his 'institutional-redistributive model of social welfare':

It sees social welfare as a basic integrated institution in society providing both universal and selective services outside the market on the principle of need. Universal services, available without distinction of class, colour, sex or religion, can perform functions which foster and promote attitudes and behaviour directed towards the values of social solidarity, altruism, toleration and accountability. (Titmuss 1970: 263)

Whether the particular forms of social welfare he outlines are adequate to sustain the forms of egalitarian social relations he aims to defend remains an open empirical question. I still hold the view that a more radical undoing of background inequalities in power and property is required. However, Titmuss brings a proper focus on the question as to what forms of social order are

\footnotetext{
7 'The real challenge resides in the question: what particular infrastructure of universal services is needed in order to provide a framework of values and opportunity bases with and around which can be developed acceptable selective services provided, as social rights, on criterion on needs of specific categories, groups and territorial areas and not dependent on individual tests of means? It is in such practical ways which do not involve an assault on human dignity, which are not socially decisive and which do not lead to the development of two standards of services for two nations that more redistribution can be affected through the social services in favour of those whose needs are greatest'. (Titmuss 1987: 139) For a related discussion see Wolff, 1998.
} 
compatible with both the recognition of human vulnerability and sensitivity to the potential humiliations that particular forms of social dependence can bring. A virtue of MacIntyre's work on dependence is the way it brings this question properly back to centre of social and political thought. My aim in this chapter has been to link this work, and specifically the criticisms of Smith, to wider arguments for equality that are evident in a particular tradition of egalitarian thought. $^{8}$

\section{References}

Aquinas, Saint Thomas. Summa Theologica [Online]. Available at: http://www.ccel.org/ccel/aquinas/summa.html [accessed: 8 September 2014].

Aristotle 1946. Rhetoric, trans. W. Roberts. Oxford: Clarendon Press.

Benson, J. 1983. Who is the Autonomous Man? Philosophy, 58, 5-17.

Blum, L., 1994. Moral Perception and Particularity. Cambridge: Cambridge University Press.

Cicero 1991. On Duties, edited by M.T. Griffin and E.M. Atkins. Cambridge: Cambridge University Press.

Crisp, R. 2008. Compassion and Beyond. Ethical Theory and Moral Practice, 11, 233-46.

Fleischacker, S. 2004. On Adam Smith's The Wealth of Nations: A Philosophical Companion. Princeton: Princeton University Press.

Galton, R. and Simpson, A. 1974. Hancock's Half Hour. London: Woburn Press.

Gray, P. 2001. A Brief History of Friendly Societies [Online]. Available at http://web.archive.org/web/20011225144332/http://www.afs.org.uk/research/researchpgray historypage.htm [accessed: 8 September 2014].

\footnotetext{
${ }^{8}$ An earlier version of the paper was given at the conference Virtue and Economic Crises ISME Mykolas Romeris University, Vilnius, Lithuania July 29 - August 1, 2010. Thanks are owed for the many helpful comments made on this occasion. The paper draws on and develops earlier arguments developed in O'Neill 2011.
} 
Hobbes, T. 1968. Leviathan. Harmondsworth: Penguin.

Hont, I. and Ignatieff, M. 1983. Needs and Justice in The Wealth of Nations, in Wealth and Virtue: The Shaping of Political Economy in the Scottish Enlightenment, edited by I. Hont and M. Ignatieff. Cambridge: Cambridge University Press.

Kant, I. 1979. Lectures on Ethics. London: Methuen.

Locke, J. 1988. Two Treatises of Government. Cambridge: Cambridge University Press.

MacIntyre, A. 1999. Rational Dependent Animals. London: Duckworth.

Marx, K. 1973. Grundrisse. Harmondsworth: Penguin.

Marx, K. 1974. Economic and Philosophical Manuscripts. Early Writings. Harmondsworth: Penguin.

Mauss, M. 2002. The Gift. London: Routledge.

Nussbaum, M. 2001. Upheavals of Thought: The Intelligence of Emotions. New York: Cambridge University Press.

O'Neill, J. 1998. The Market: Ethics, Knowledge and Politics. London: Routledge.

O'Neill, J. 2011. The Political Economy of Recognition. The Adam Smith Review, 6, 129-51.

Rousseau, J.J. 1911. Emile, trans. B. Foxley. London: Dent.

Rousseau, J.J. 1984. A Discourse on the Origin of Inequality. London: Penguin Books.

Smith, A. 1981 . An Inquiry into the Nature and Causes of the Wealth of Nations. Indianapolis: Liberty Press.

Smith, A. 1982a . Letter to the Edinburgh Review. Essays on Philosophical Subjects. Indianapolis: Liberty Press.

Smith, A. 1982b . The Theory of Moral Sentiments. Indianapolis: Liberty Press.

Smith, A. 1982c . Lectures on Jurisprudence. Indianapolis: Liberty Press.

Tawney, R. 1964. Equality. London: Unwin.

Titmuss, R. 1987. The Philosophy of Welfare: Selected Writings of Richard M. Titmuss, edited by B. Abel-Smith and K. Titmuss. London: Allen and Unwin. 
Titmuss, R. 1970. The Gift Relationship. London: Allen and Unwin.

Wolff, J. 1998. Fairness, Respect, and the Egalitarian Ethos. Philosophy and Public Affairs, 27, $97-122$. 